\section{THE MEANINGS OF THE HORSE-FACED MASK IN THE STORY OF KAEO NA $M A^{1}$}

\section{Cholada Ruengruglikit $^{2}$}

\begin{abstract}
This paper aims to study the meanings of the heroine's horse-faced mask in the story of Kaeo Na Ma. The two versions investigated here are the version composed by Prince Phuwanetnarinrit and that of the Ratcharoen written by Nai But and influenced by the former version. Since Prince Phuwanetnarinrit's version firstly indicates that the heroine's horse face can be removed, it is considered as a mask in this paper. Like other masks in Khon or masked drama, the horse face controls the behavior and personality of the wearer. This horse face not only signifies the heroine's tomboyish manners as stated in other studies, but also communicates various hidden meanings complying with her other characteristics and behaviors. Five meanings are discussed here including the heroine's unrefined behavior, self hiding, protective gear, ugliness and peculiarity, and masculinity. All of these
\end{abstract}

1 Revised from the paper entitled 'The Significance of the Horse-faced Mask in the Story of Kaeo $\mathrm{Na}$ Ma', presented at The Ninth International Conference on Thai Studies held by Northern Illinois University, DeKalb, Chicago, USA, 3-6 April 2005

2 Associate Professor, Department of Thai; Director, Research Center of Thai Language and Literature, Faculty of Arts, Chulalongkorn University, Bangkok, Thailand. meanings also exist in Thai sayings, in some literary works, and in the context of the story itself. This horse-faced mask enables the heroine to present her 'self' in three different guises and personalities, namely the character of a comedian in the figure of Nang Kaeo; a heroine in the figure of Nang Mani; and a hero in the figure of Manop, an unnamed man. Compared to the abstract meaning of wearing many masks at the same time, Nang Kaeo is very efficient in performing several duties at the same time. She takes good care of her family and society. It can be said that she is really the first warrior heroine in Thai literature and has much influence on other warrior heroines in Thai tales. Nonetheless, as beauty is a typical characteristic of Thai heroines, the hero in this story has to remove Nang Kaeo's horse face before appointing her his queen - the act that proves the denial of an ugly heroine in Thai tales.

\section{Introduction}

The story of Kaeo $\mathrm{Na} \mathrm{Ma}$ is one of the most well-known Thai folktales. It is popular among Thais because its heroine is strange and different from other heroines in Thai tales. Unlike others, she is a laughable girl whose face is ugly. Some versions of this story clearly indicate that her ugly face is like that of a horse. Her horse face is outstanding because she is the only one among all heroines in Thai tales who owns this kind of face. Her face is also interesting because it can be removed. The wearer can take it off and put it back on according to her will. Thus I consider her face as a mask. This mask enables her to appear in various guises and different roles. The meanings of this horse-faced mask calls for careful study. 
This paper aims to study the meanings of the heroine's horse-faced mask in the story of Kaeo $\mathrm{Na} \mathrm{Ma}$. The work of Prince Phuwanetnarinrit, the folk dance-drama version, is used as a main text. Additionally, the Ratcharoen version known as Wat Koh is also used at times to support my ideas. The hypothesis for the study is that the heroine's horse-faced mask in the story of Kaeo $\mathrm{Na} \mathrm{Ma}$ has several hidden meanings related to the character and behavior of the heroine. This paper is divided into three main sections. The first section is the background to the story of Kaeo $\mathrm{Na} \mathrm{Ma}$ and its narrative. The second is the background to the masks in Thai society and performance. The third is the meanings of the horse-faced mask in the story of Kaeo $\mathrm{Na} \mathrm{Ma}$

\section{Background to the Story of Kaeo $\mathrm{Na}$ $M a$ and Its Narrative}

The story of Kaeo $\mathrm{Na} \mathrm{Ma}$ is a Thai folktale originating in central Thailand. Some scholars, notably Akhavit Ruengrong, say that this story was composed in the form of a Klonsuat called Pinthong Klonsuat in the late Ayutthaya period (Akhavit Ruengrong, 1996:30). He presents his idea by considering some words that are similar to those in the works of the late Ayutthaya period and also on some prosody he has misunderstood that it is a kind of Ayutthaya versification. In my opinion, similar words are not enough evidence to indicate it as a work of the late Ayutthaya period and this similarity can easily be imitated from the old works. Other scholars such as Udom Rungruengsri shares the same idea (Udom Rungruengsri, interviewed, 1994: June 6, cited in Akhavit Ruengrong, 1996:8). I think that this work was written in the early Bangkok period because of its very modern heroine and some elements that were influenced by Sunthorn Phu's works. These points will be discussed later.

The story of Kaeo $\mathrm{Na} \mathrm{Ma}$ is very popular throughout the country except in the northern area. One reason may be that the story is so unconventional that it is not suitable for the northern poets or monks to use it in their moral teachings. Besides, Nang Kaeo, the heroine, breaks some social norms, so she is not a good archetype in the eyes of northern poets or monks.

This story is known by different titles depending on the emphasis given to the hero or heroine. It should be noted here also that even the hero's and heroine's names vary. Their different titles include Pinthong Klonsuat, Sappadon Khamkap, Bot Lakhon Rueang Phinthong, Kaeo Sappadon, and Kaeo Na Ma.

This story is written into two forms: prose and poetry. It is noticeable that some prose versions include some poetry from other poetry versions. For example, So Phlainoi's work is a prose narrative inserted with some poetry drawn from the Ratcharoen version.

The poetry group itself can be subdivided into two small classifications: reading and performing. Pinthong Klonsuat, Sappadon Khamkap, Nithan Khamklon Rueang Kaeo $\mathrm{Na} \mathrm{Ma}$ composed by Nai But, and Khamklon Rueang Kaeo $\mathrm{Na} \mathrm{Ma}$ of Isan created by $O$. Kawiwong, are in the reading poetry classification (Akhavit Ruengrong; 1996:2-3). Bot Lakhon Rueang Phinthong and Bot Lakhon Nok Rueang Kaeo Na Ma or the folk dance-drama version of the story of Kaeo $\mathrm{Na} \mathrm{Ma}$ are good examples of the latter classification.

Focusing on the outstanding face of the heroine, the story can be divided into two categories. Firstly, the story in which the 
heroine has an ugly face. Secondly, the story in which the heroine has a horse-faced mask. For this study, the story in second category is paramount. Two versions in this category are discussed. The folk dancedrama version composed by Prince Phuwanetnarinrit is used as a main text. The Ratcharoen version is used at times to support my ideas.

The folk dance-drama version of Prince Phuwanetnarinrit, one of the most wellknown playwrights in the early Bangkok period, is well regarded among readers and audiences. He is one of King Rama II's sons. He was born in the reign of King Rama I in 1801 (So Phlainoi, 1990:38). He started his works in the reign of King Rama II and continued until the next two reigns (So Phlainoi, 1990:39-42). He died at the age of fifty-six in the reign of King Rama IV. During the periods of King Rama III and King Rama IV, Thai performances, especially folk-dance drama or Lakhon Nok, grew widely (Tamnan Lakhon Inao, 1964: 154-55; Phraya Chaiwichit (Phueak), 1975: 33). Many aristocrats and officials usually had their followers practice folkdance drama. Some even owned the groups of actors. Consider Prince Phuwanetnarinrit, like his two brothers, Prince Phiphitphokphuben and Prince Phithakthewet, established a group of actors to play a folk-dance drama (Tamnan Lakhon Inao, 1964:159). He, as a skillful playwright, composed in the reign of King Rama IV five well-known folk dancedrama scripts for his actors. These are Kraithong, Maniphichai, Suwannahong, Thewan-Nang Khula, and Kaeo Na Ma (So Phlainoi, 1978:42). Among these works, Kaeo $\mathrm{Na} \mathrm{Ma}$ is his most well known. For this work, he was the first poet who changed or adapted the heroine's ugly face to the horse-faced mask. This might come from the reason of giving possibility and convenience to remove the heroine's horse face in performance and using this horse face to color the story. However, there are still other reasons that call for discussion. The horse face is also used as an important literary technique to symbolize the heroine's several equine characteristics and behavior. This point will be discussed later.

The other version, the Ratcharoen known as Wat Koh and titled Nithan Khamklon Rueang Kaeo $\mathrm{Na} \mathrm{Ma}$ was written by Nai But in the reign of King Rama V. He was an expert and famous poet who composed many Nithan Khamklon for the Ratcharoen. His works were very popular in that period though his biography is not yet wellknown.

Regarding the content of the story, Prince Phuwanetnarinrit's work is an unfinished version. The story ends at a quarrel scene between Nang Mani Sri Mueang and Princess Thatsamali who came to call Phinthong back to her city. The Ratcharoen version follows the episodes in the former version and also adds some details. Nai But furthers events including the love and adventures of Nang Kaeo's children and grandchildren. In this version, Pinkaeo, Nang Kaeo's son, wears the horse-faced mask of his mother in order to hide during his adventures. These two folk dancedrama and the Ratcharoen versions are the archetypes of the other various versions composed after them.

Before going in detail, it is necessary to give the narrative of both versions as background.

\section{The Narrative of the Folk Dance-drama Version}

This is a story about the love and life of the heroine, a horse-faced girl named Nang 
Kaeo. Though she is ugly and laughable, she passionately desires the handsome Prince Phinthong at first sight and tries to make him her husband. This brings many difficulties to her life before she succeeds.

Prince Phinthong of Mithila city loses his kite while playing with his followers. Nang Kaeo gives it back on the condition that the prince promises to accept her as his consort. He then gives a pledge to send his followers to take her to the palace in a few days. Nang Kaeo asks her parents to follow up the prince's promise. The prince's father, the king, is furious that a folk girl of humble birth longs to marry his son. He then orders Nang Kaeo to bring to him Mount Meru and, if not she will be punished to death. Though having no idea where it is or how to get it, she determines to do so without giving up. Afterwards, a hermit whom she has met in the forest feels sympathy to her and gives her a magical flying boat and some tools to help her fulfill her task. The king inevitably allows his queen to send her followers to take Nang Kaeo to his palace. The prince is then depressed and tries to run away from Nang Kaeo who has tried to be close to the prince. He solves the problem by leaving for Romwithi city to marry Princess Thatsamali. Before his departure, the prince orders Nang Kaeo to have a baby with him when he comes back. After his leaving, Nang Kaeo goes back to the same hermit. The hermit helps remove her horse face and changes her into Manop, her male disguise. Later on, by taking off her horse face, she is also capable to change herself into Nang Mani, her beautiful guise. At her first changing, the hermit gives her beautiful dresses and points out to her where Romwithi is. She arrives there and lives with a generous old couple. One day, upon knowing that the prince will pass by, she, in her beautiful guise of Nang Mani, pretends to bathe in the canal to attract him. At first sight, he sees her beauty and falls in love with her. He tries to win her heart and makes her his by visiting her at the old couple's house, though in vain. She resists his will and love because she would like to torture him as he paid no attention to her when she was Nang Kaeo. Knowing that he has no more patience, she consents to be his as she is afraid of losing him. Without Princess Thatsamali's recognition, the prince secretly lives with Nang Mani until she is pregnant. Later on, the prince's father calls him back. Before leaving, the prince asks Nang Mani to go with him, but she denies. Therefore he gives her his red cloth and a ring to give to her forthcoming baby. On the way back to Mithila, the prince accidentally enters the demon city of King Phanlarat. This demon King would like to eat him and his followers. He orders his demons to round up the victims. Nang Mani brings her baby to say farewell to the hermit before turning back to show her baby. As soon as she knows from the hermit that the prince is in danger, she leaves her baby with the hermit to be looked after and rapidly goes to help the prince in her male disguise, Manop. Manop meets the prince and tells him to wait in the ship during Manop's fighting. Being afraid of the demons, the prince does not let Manop go away by forcibly gripping Manop's hands. As a result, Manop has to pull him up on horseback and lets him go on the same horse. Finally, Manop kills the demon king and receives the demon's two daughters, Princess Soisuwan and Chanthon, from Phinthong after the victory. Manop brings them to the hermit's residence and shows them her other two figures, Nang Kaeo and Nang Mani. After that Manop allows these two princesses to be the prince's consorts. When the prince arrives at his city, Nang Kaeo shows him her baby, though the prince misunderstands 
that Nang Kaeo has stolen Nang Mani's baby. However, noticing Nang Kaeo breast-feed her child makes him confused. Afterwards, the prince sees that Princess Soisuwan and Chanthon are in the power of Nang Kaeo. He then forces them to confess. Knowing that Nang Kaeo, Nang Mani, and Manop are the same person, he feels gratitude to Manop who saved his life, his people, and his country. Additionally, he loves Nang Mani who wins his heart. However, he chooses neither Nang Mani nor Manop, but would like Nang Kaeo without her ugly face to be his queen. Thus, he with the help of Princesses Soisuwan and Chanthon, successfully tricks Nang Kaeo into taking off her mask. After that the prince becomes king and appoints Nang Kaeo as his queen named Nang Mani Sri Mueang. Princess Thatsamali comes to Mithila to call Phinthong back to her city. Phinthong claims he is sick and cannot go by himself to pick her up to his palace. When Princess Thatsamali enters the palace and sees Nang Mani Sri Mueang, Princess Soisuwan and Chanthon with her husband, she is jealous and quarrels with them. The story of this version stops at this event. This is the unfinished end.

\section{The Brief Story of the Ratcharoen Version}

The story in the Ratcharoen version repeats the episodes in the folk dance-drama version, and some more details are added. For example, Nang Kaeo's mother dreams of receiving a precious gem from a god before she is pregnant. Nang Kaeo has gifted knowledge. She can tell her neighbors where there is drought or where is good for agriculture. The episode of killing the demon Prakaimat before the prince tricks Nang Kaeo to take off her mask and the episode of killing the demon Prakaikrot before Princess Thatsamali comes to Mithila city are also added. However, there are some differences between these two versions. The name of the prince in the Ratchroaen version is Pinthong, not Phinthong as in the dancedrama version. Moreover, in this version Nang Kaeo's horse-faced mask cannot be burnt after the hero has tricked Nang Kaeo into taking off her mask and set it on fire while it is burnt to ashes in the folk dancedrama version. It should be noted here that the Ratcharoen is accepted as the most complete version.

The events in the Ratcharoen added to the suspended story in the folk dance-drama version can be summed up as follows. Nang Mani Sri Mueang's triplet daughters, Chamchan, Hiranyarat, and Praphatsorn, are taken away by a Hatsadin bird while they are visiting their garden. Fortunately, a hermit saves them from being eaten by the bird. He brings them up and afterwards lets them marry three men. Regarding Princess Thatsamali, she casts a spell on Pinthong, so he flees from Nang Mani Sri Mueang, Princess Soisuwan, and Chanthon to live with Princess Thatsamali. Nang Mani Sri Mueang, Princess Soisuwan, and Chanthon have followed him and try to free him from the power of Princess Thatsamali, but they are arrested by her army. Finally, Prince Pinkaeo and his younger sisters successfully free Pinthong from the power of Princess Thatsamali. All of them, including Pinsinchai, Princess Thatsamali's son, return to Mithila. Later on, Prince Pinkaeo wears Nang Kaeo's horse-faced mask and leaves his city in order to accompany Pinsinchai back to Romwithi. On their way, they separate, have many adventures, and meet each other again. Finally, Prince Pinkaeo becomes the king of Mithila. Pinsinchai rules Chakkrawat. After his sons and daughters have their descendants, 
Pinthong and all of his wives are ordained. At the end of the story, the hermit Pinthong stops one of his grandchildren's quarrel with another prince competing for the same woman. After that, all of them live peacefully and happily ever after.

\section{Background of the Mask in Thai Society and Performance}

In Thai society, there are two kinds of masks. One is a mask feigning only the face. This kind of mask is frequently used in many parties. The masks of the Red Eagle Hero and the Red-hooded Lady in Thai films are good examples of this kind of mask. The other kind is a mask covering one's entire head. The lion-headed mask in the Chinese lion dance, the big and smilefaced masks of Pae Yim and Ah Sim in the Chinese lion dance, Khon masks in masked drama, and the Negrito mask in the folk dance drama of the story of Sangthong are good examples of the latter kind.

The masks used in the parties in Thai society are hiding the wearers' real faces. The Negrito mask in the folk dance drama of the story of Sangthong hides the hero's real face like the masks used in the parties. But in Thai masked drama, each mask signifies the behavior and outstanding characteristics of the wearer. For example, an actor wearing the ten-headed mask is assigned to play the role of Thotsakan or Ravana, the powerful demon king. He is self-indulgent and has to stamp his foot when he is furious. Wearing the mask of Hanuman, the clever and tricky monkey in the same story, the actor has to scratch his chin, arms, or his back in the manner of a monkey. Additionally, as Hanuman is a philanderer, the actor who assumes this role always woos beautiful ladies whom he has met.
Though the heroine's horse-faced mask in the story of Kaeo $\mathrm{Na} \mathrm{Ma}$ is like some other entire-headed masks, it is different from others. The heroine's horse-faced mask in the original version, Pinthong Klonsuat, is a part of the heroine's body while other masks are not. When the heroine wears it, it does not at all look like a mask. It is absorbed and covers her entire real face. This is a very important point and means that the heroine never knows before meeting the hermit that her ugly horse face is only a mask. However, this is impossible in performance. How could the actress who plays the role of Nang Kaeo take off or put her horse face on again if it is not a mask? To solve this problem in performance, Nang Kaeo's horse face is changed from a horse face which is a part of the heroine's body to a mask. This change started in the folk dance-drama version composed by Prince Phuwanetnarinrit.

Regarding the abstract meanings of wearing masks, 'suam hua khon' in spoken Thai which means wearing Khon mask signifies holding an important position and being responsible for some special work. By this meaning, one can do different duties, one by one, according to one's different position and responsibility at each time.

The meanings of the mask both in Thai society and performance give much help to explore the meanings of the heroine's horse-faced mask in this paper.

\section{The Meanings of the Horse-faced Mask in the Story of Kaeo Na Ma}

Five meanings of the heroine's horse-faced mask in the story of Kaeo $\mathrm{Na} \mathrm{Ma}$ are found.

Its first meaning is the heroine's unrefined behavior. As mentioned above, 
each performing mask determines the behavior and outstanding characteristics of the wearer. The horse-faced mask of Nang Kaeo also has the same role. Covered with a horse face, Nang Kaeo behaves like an untamed horse that is always knocking its head and kicking. She likes to jump and run to and fro with a loud noise. She likes to laugh loudly like a crying horse, shrug her neck, and nod her head in the manner of a horse (p.143, 153). In addition, when Phinthong tries to reunite with her, she bites him (p.178). This is a horse's manner in fighting and preventing itself from harm (Saranukrom Watthanatham Thai Phak Nuea, 1999.10: 5127).

In the Ratcharoen, Nang Kaeo's laughable manner and clumsiness are stressed. When the prince's mother sends her followers to take Nang Kaeo to the palace, Nang Kaeo dresses in a ridiculous manner. This gives her a laughable look. However, the royal followers pretend to flatter her that she is as beautiful as a goddess. This pleases Nang Kaeo so much that she clumsily steps on the old chief court lady who is in charge of taking her to the palace. This lady therefore scolds Nang Kaeo in sarcastic words having an unrefined manner, though she longs to be the prince's consort (Ratcharoen version, 1957.1:25-26).

In addition, by her will, she goes very close to Princess Thatsamali who is sleeping in Phinthong's chamber, intentionally flicks her long strip of cloth on the princess's head, and afterwards pretends to say sorry to her (Ratcharoen version, 1957.4:24). In this very bad manner she intends to show her dislike towards Princess Thatsamali.

In the Thai language, there are the phrases 'ma phayot' and 'ma did kalok'. 'ma phayot' means a stubborn horse which does not listen to its trainer. ' $m a$ did kalok' is used to call a woman who behaves like an untamed horse (Kanchanakkhaphan, 1998:415). An untamed horse usually likes to kick and knock its head all the time and is difficult to control. In the case of Nang Kaeo, she could not be idle and has an equine appearance as said before.

However, Nang Kaeo is in fact a refined and courteous woman. She pretends to be an unrefined woman to tease others who disdain her. The hermit knows this fact well. He reminds Nang Kaeo when she leaves him to love her horse face no more and to quit her unseemly behavior. This is said in the text by the hermit that 'ya rak rup na ma batsi' which means do not love your ugly horse-faced mask (p.141) and 'khondi tham ba ku na chang' (p.141) which means the hermit dislikes seeing Nang Kaeo, a normal girl, pretend to be nutty.

Furthermore, her unrefined behavior is unconventional. She seeks Phinthong's love and argues with him by using equivocal words. She tries to be close to Phinthong by entering his chamber, fanning him, massaging him, holding him, kissing him, and assaulting him, even though Phinthong tries to escape from her (pp.2729). She parodies her husband, her father and mother in law whom she should pay her respect to. These deeds vividly break the social norms and cause her to be called 'sappadon'. This word means a nonconformist or an unconventional woman. Thus, in the story, she is frequently called Nang Kaeo Sappadon (pp.41, 137) or Nang Sappadon (p.23) etc.

Its second meaning is the heroine's self hiding. In Thai folktales, some heroes hide themselves in a form of animals. For example, Phra Sang hides himself in a conch shell and later on in a Negrito mask in 
the folk dance-drama of Sangthong. Besides, some heroes hide themselves in an ugly figure such as King Kutsarat in Kusa Jataka. In the story under discussion here, it is the heroine who hides her real face and her beauty beneath her horse face.

Before the hermit teaches Nang Kaeo to take off her horse face, none, including Prince Phinthong, could see her beauty. Moreover, they laugh at her ugly and extraordinary face and disdain her. It is noticeable that even her mother accepts her daughter's ugliness and scariness. She says that it is impossible for Nang Kaeo to be Prince Phinthong's consort (p.9). Many characters in the story try to convince Nang Kaeo to leave her mask, knowing that the mask hides her beauty. For example, the hermit tells her that she should no more love her ugly mask (p.141). Phinthong's parents say that Nang Mani should not hide her beauty beneath an ugly horse mask (p.186). Phinthong burns the horse mask to ashes because he does not want Nang Kaeo hiding her beautiful face by wearing this mask (p.177).

In the Thai language, there are the words 'phom ma', conveying the meaning of hiding. "phom $m a$ ' is a hairstyle that means bangs. This hairstyle lets some hair fall down to cover a part of one's forehead (The Royal Institute Dictionary, 1999:726). It can be said in other words that the bang gives a good look to the female owner by hiding a part of her forehead.

Its third meaning is as a protective gear. Wearing her horse face, Nang Kaeo can go everywhere without harm. It is accepted that femininity, especially woman's beauty, is very dangerous for the owner. During the war in the late Ayutthaya period, Thai women shortened their hair and dressed as males in order to protect themselves from easily being raped by the Burmese invaders. Due to Nang Kaeo's ugly face, none are interested in her. In searching for Mount Meru, Nang Kaeo is safe throughout her trip. The hermit who is Nang Kaeo's helper also has this same idea. After teaching her to remove her horse-faced mask, the hermit reminds her to take this mask with her to protect herself from harm. The phrase 'chuai kan phai' which means help to protect from harm is used to clearly express the horse mask as the heroine's protective gear (Ratcharoen version, 1957.1: 43).

In Thais' idea, woman's chastity is very important. Her chastity makes her considered virtuous in the eyes of men, especially her husband. This idea is always portrayed in Thai classical literature. One excerpt from Suphasit Son Ying effectively supports this idea. It is said that as soon as women keep their virginity, they are considered worthy as valuable gems, if not they are compared to broken gems that are priceless. This idea is as quoted below:

Pen sao suai rae ruai suai sa-at ko mai mat muean mani an mi kha Maen taek rao ran roi thoi rakha cha phloi pha hom hai chak kai nang (p.521)

This idea well portrays why a woman's virginity is so important in Thai society and why the heroines in Thai tales have to protect themselves from the villains in order to show their loyalty to their husbands during their separation.

Its fourth meaning is the heroine's ugliness and peculiarity. Nang Kaeo's face is said to be longer than normal. In the Ratcharoen version, Pinthong's father says that Nang Kaeo's face is ugly because it is half a meter long and looks like a horse 
face. This is said in the text as ' $\boldsymbol{n a}$ sak sok klok ta muean ma thet' (Ratcharoen version, 1957.1:27). Princess Thatsamali shares the same idea. She says that Nang Kaeo's face is more than half a meter long and looks ridiculous as said in the text: 'phak sak sok nueng kwa du na khan' (Ratcharoen version, 1957.4:26). This might come from the actual horse's face which is generally long (Saranukrom Watthanatham Thai Phak Nuea, 1999.10: 5126).

In ancient Thais' idea, the ideal face of Thai women should be round like that of people in Jumphu as said in Traiphumikatha (Wannakam Samai Sukhothai, 1985:68). This round shaped face is similar to the shape of the hub of a cartwheel. But Nang Kaeo's face is long and peculiar, so her face is unique and is not beautiful at all in the eyes of Thai people in the past.

In the Thai language, the phrase ' $n a m a$ ' is used to call a girl who has a longer face than usual and sometimes includes a girl who has a projecting chin or teeth. These are the outstanding appearances of a horse.

In the Thai language, there is also the expression 'na ngo pen ma makruk'. It means putting on a long face that implies it is as ugly as a horse's face. A chess horse face or ' $m a$ makruk' is considered even uglier than that of a living horse. So, using a horse to communicate the meaning of ugliness is easily understood in Thai society. In the story, the heroine's horse face is frequently described to indicate her ugliness.

Its fifth meaning is the heroine's masculinity. It is found that a horse is frequently used to represent a man. In the story of Inao, the heroine, Butsaba, is forced to disguise herself as a man by her divine ancestor, Patarakala. In her male guise, Butsaba is given a new name, Unakan, that means horse. After receiving this name, Butsaba acts as a hero. Unakan spreads out mighty power and gets a lot of ladies from waging wars.

In the story of Kaeo $\mathrm{Na} \mathrm{Ma}$, it is the poet's genius to find an amazing way to represent masculinity in the heroine's body by adding a horse face to her.

Nang Kaeo, especially while wearing the mask, has both femininity and masculinity. Her unidentified characteristics confuses even herself because she does not know at all how to manage these two different characteristics which cause her to be different from other women. She is reckless while others are bashful and excitable. She can frankly express her feelings and desires to the man with whom she falls in love. Moreover, she has great bravery while other women are weak. She can fight as a warrior while others cannot. This makes her considered an unconventional girl. In other words, she has prominent bravery that is a male appearance.

Her unidentified characteristics also confuse the hermit. At first sight, he sees that she is a woman, but, after a minute, he is not sure. He therefore asks if she is either a man or a woman. In the text, 'prasok rue sika' means a man or a woman is the hermit's question (p.15).

After knowing that she is a woman, the hermit admires her brave heart for coming alone to the forest in order to prove her great love and to fulfill the king's command. Being impressed by her bravery, the hermit helps her bring Mount Meru by giving her a magic flying boat and the necessary tools to dig out the mount. 
It could be interpreted here that the hermit's help removing Nang Kaeo's horse face when she followed the prince to Mithila is in fact the hermit's teaching Nang Kaeo proper behavior when she would like to act as a man or as a woman. So, later on, Nang Kaeo is no more confused about her unidentified characteristics. She could perfectly play the role of either a woman or a man according to her will or circumstances.

As said above, Nang Kaeo's horse-faced mask is different from other masks because it is a symbol of her characteristics and behavior. No matter if she wears her mask or not, her characteristics complying with the hidden meanings of the horse face are still in her character.

Nang Kaeo can appear in three different figures; the figure of Nang Kaeo with both femininity and masculinity, Nang Mani with only female appearance, and Manop with only male appearance. By taking off and putting on her horse face, Nang Kaeo plays all three different roles: the role of a heroine, of a hero, and of a comedian. She plays the role of a comedian in the figure of Nang Kaeo, the role of a heroine in that of Nang Mani, and the role of a hero in that of Manop.

The figure of Nang Kaeo is laughable because of her horse face, her equine manners, and her unconventional deeds. For example, she dresses up in a ridiculous outfit before going to the palace. She wears a red tube skirt, articles of low-graded gold, and powders her face an inch thick.

Nang Mani is the beautiful and gentle figure of Nang Kaeo after she has learned how to behave as a normal girl. This figure appears when she lives with the old couple in Romwithi and aims to win the prince's heart. This figure represents an ideal woman who is perfectly beautiful and very gentle. Like Phra Phuean and Phra Phaeng in Lilit Phra Lo of the early Ayutthaya period, she carries out her plan in the manner of a naive girl in spite of her unconventional intention to seduce the prince. She attracts him by bathing in a canal where the prince has to pass by. Knowing that the prince is peeping at her, she comes up from the canal, sits on a bridge, scrubs her body, and bathes in order to arouse his sexual desire (p.63). Later, when he visits her residence, she pretends to refuse him though she in fact would like him to be her husband (pp. 67-83). She intends to torture him as long as possible and takes a little revenge on him as he has hated and disdained her when she was Nang Kaeo. Nang Mani's performance shows that her behavior do not break the social norms. Finally, by the attempt of the hero, by her love, and by her recognition that the prince has no more patience, she lets the prince win her heart. In the figure of Nang Mani, she plays not only a wife's role, but also a mother's. She is pregnant, gives birth to a baby, and lulls him to sleep (pp.88, 103, 136-37). Anyway, Nang Mani is also like an untamed horse in another aspect, she is difficult to control. Unlike other heroines who are usually seduced by the hero and finally become his wives, Nang Mani is not. If she does not consent to be his wife, the hero cannot force her to. In the story, Prince Phinthong tries many times to win her heart, but in vain. After Nang Mani realizes that the prince has no more patience and she is afraid of not being able to fulfill her plan, she then accords to his will (Ratcharoen version, 1957.1:38). This is quite similar to Princess Suwannamali and Queen Laweng in the story of Phra Aphai Mani. When they do not consent to be Phra Aphai Mani's consorts, he cannot force them to. Both of them know their own defects and can 
prevent themselves from being his wives. They decide to get away from his wooing. The episode well proving this idea is when Princess Suwannamali has dressed as a male Persian and goes out of her bedroom in order to escape from Phra Aphai Mani (Phra Aphai Mani Khamklon Khong Sunthorn Phu, 1966:323). When Queen Laweng first fights against him and he plays his flute to win her heart, she is much afraid of being unable to resist his love, so she drives her horse away into the forest (Phra Aphai Mani Khamklon Khong Sunthorn Phu, 1966:531-536). Later on, when Phra Aphai Mani stays in Langka and enters Laweng's bedroom, he cannot convince her to be his. He pretends to tie up his neck, Laweng then consents to be his wife (Phra Aphai Mani Khamklon Khong Sunthorn Phu, 1966:688-689). Princess Suwannamali, Queen Laweng, and Nang Mani are good examples of unconventional heroines who are so determined that even the heros cannot force them.

Though it is told in the story that Nang Kaeo uses a magic bush knife given to her by the hermit to transform into Manop, a young man, it could be interpreted that Nang Kaeo only dresses up in a male outfit. In the Ratcharoen version, while the prince has been blindly in love with Princess Thatsamali and stays with her, Nang Mani Sri Mueang, followed by Princess Soisuwan, and Chanthon, goes to Romwithi to call the prince back. Princess Thatsamali sends her army to arrest Nang Mani Sri Mueang, Princess Soisuwan, and Chanthon. In her Manop disguise, Nang Kaeo fights against Princess Thatsamali's soldiers. Before fighting, Manop asks Princess Soisuwan and Chanthon to disguise as males. The words 'taeng plaeng ong... hai lamai pen chai chan' are clearly used. Both of them wrap around their breasts in order to present themselves as men (Ratcharoen version, 1957.7:28). This indicates that, in reality, Manop is not a man, but a woman disguised in a male appearance when taking the role of fighter. Besides, the Manop figure appears when Nang Kaeo rescues the prince from being eaten by the demon Phanlarat and his giant followers (pp. 12228). In other tales, it is the hero who plays the role of fighting against the villains and rescuing the heroine when she has been kidnapped or in danger, but in this story, the heroine in a male disguise plays this role instead. The hero in this story never helps the heroine. In contrast, the heroine always saves the hero's life. Additionally, she protects the lives of Mithila's people and also of the country of her alliance from invaders. At each time of being attacked, it is Manop who leads the army to fight against the enemies even though she is ready to give birth.

A female disguise in a male figure might come from the idea that a man fears losing his dignity when fighting against a woman who is considered weaker than a man. In the Ratcharoen version, Manop fights against the demon King Prakaikrot who leads the army to attack Mithila in order to take revenge on his two deceased friends killed by Manop, King Phanlarat, and King Prakaimat. At that time, though Nang Mani Sri Mueang is about ready to deliver her baby, she, in the disguise of Manop, bravely wages a war with King Prakaikrot and finally is victorious. During the fighting, King Prakaikrot forcefully kicks at her stomach and immediately causes her to give birth to triplets. This frightens and surprises King Prakaikrot very much for he never knew that Manop was not a man. He then disappointedly and shamefully complains about fighting against a woman without knowing as quoted below: 


\author{
Woei satri mueng klaeng chamlaeng \\ rangtham amphrang hai ku long mai \\ songsai \\ Ma yuen ning kom na wa rai \\ ku ai chai khran cha kha ko prani \\ (Vol.5, p.29)
}

The words 'chamlaeng rang' here have the same meaning as 'plom plaeng taeng kai muean chai' (Phra Aphai Mani Khamklon Khong Sunthorn Phu, 1966:323) in Phra Aphai Mani. Princess Suwannamali disguises as a male Persian when she would like to fool Phra Aphai Mani who intends to woo her and win her heart.

Prince Phuwanetnarinrit might take the idea of women's ability in waging war from the role of some heroines in Thai society or in some literary works in the early Bangkok period. In the early Bangkok period during the reign of King Rama I, Lady Chan, the wife of Thalang city's governor, and her sister, lead the Thalang villagers to successfully fight and expel the Burmese invaders from southern Thailand. In the reign of King Rama III, Lady Mo leads Nakhornratchasima villagers to successfully free themselves from being captives of the army of King Anuwong of Lao and finally get victory over them. Otherwise, the poet might get this idea from some literary works written before. In Inao, Patarakala shortens Butsaba's hair and forces her to dress up in a male outfit named Unakan (Rueang Inao Phra Ratchaniphon Ratchakan Thi Song, 1971:562). Unakan, or in fact Butsaba, can successfully fight. It is surprising that the meaning of Unakan is a horse. This obviously shares the same idea of Prince Phuwanetnarinrit in disguising Nang Kaeo under the horse mask. In Phra Aphai Mani, Princess Suwannamali disguises as a male Malaysian in helping Sinsamut fight against Utsaren (Phra Aphai Mani
Khamklon Khong Sunthorn Phu, 1966:301). After getting victory, she also disguises herself in a male Persian appearance in order to cause Phra Aphai Mani not to recognize her when he wants to win her heart (Phra Aphai Mani Kamklon Khong Sunthorn Phu, 1966:323).

As mentioned above, women can lead the army in a war like men do. Manop dares to wage a war while the prince dares not. Manop always fights against the invaders as the representative of the prince, her husband. Even though she is ready to deliver, she can successfully do the two male and female tasks at the same time - fighting bravely against King Prakaikrot and giving birth to her triplet daughters. After delivery, her soldiers hold her three daughters safely. She furthers her fighting and kills King Prakaikrot though she has not rested after giving birth. This surprisingly proclaims women's capability as superior to men in this story.

It is interesting that Manop or Nang Kaeo's delivery while waging war has a great influence on other heroines in other tales composed later on. They behave as Nang Kaeo does. Those warrior heroines are Nang Khan Thong and Nang Malai Thong in the story of Khan Thong (Khan Thong Vol.5: 197) and in the story of Phuang Malai Thong (Phuang Malai Thong Vol.22:1031) respectively.

Focusing on the heroine's different names, it is interesting to find that both ' $k a e o$ ' and 'mani' have the same meaning, i.e. a precious gem, but they indicate different status. 'Kaeo' is a common Thai word. She is called by this name when being a villager before she is appointed queen. The name 'mani' comes from the Indic word that is considered a higher rank than ' $k a e o$ '. This name is used when Nang Kaeo assumes a beautiful figure and when she is one of the 
prince's consorts. When she is queen, she is named by adding some words indicating her even higher status, i.e. Nang Mani Sri Mueang. The words Sri Mueang here mean being auspicious to the city. These names show the poet's knowledge in language to signify the different status of the three different figures of the heroine. Regarding the same meaning of these different names, it communicates that Nang Kaeo, Nang Mani, or Nang Mani Sri Mueang is actually the same woman but presented in different appearances. It should also be noted here that Manop is not a proper name, but only a common word carrying the meaning of a man.

\section{Conclusion}

This paper discovers the meanings of Nang Kaeo's horse-faced mask that have never been discussed before. This mask is the poet's literary technique to communicate to the audience Nang Kaeo's several hidden characteristics and behavior. By studying the concepts and the beliefs concerning a horse through Thai expressions, some Thai literary works, and the context of the story itself, five hidden meanings of Nang Kaeo's horse-faced mask are revealed. These are the heroine's unrefined behavior, self hiding, protective gear, ugliness and peculiarity, and masculinity. All these meanings found in this paper conform to both the characteristics of a horse and that of Nang Kaeo. Unlike other masks that control the performance of the wearers when the masks are on their faces, Nang Kaeo's horse mask is the symbol of her characteristics and it controls her behavior even when she does not wear it. Putting on and taking off the horse face enables Nang Kaeo to appear in three different guises and to play different roles. With this horse face, Nang Kaeo appears both as the straightforward comedian heroine and the warrior heroine - the two new types of heroine in Thai tales. She is laughable in her peculiar face and behavior. She not only has the courage to reveal her love to the prince but also fights as a great warrior. She is the first great warrior heroine who gives birth to her triplet daughters while fighting against a mighty hostile demon, King Prakaikrot, and finally wins the war. Nang Kaeo is the prototype of Nang Khan Thong in the story of Khan Thong and Nang Malai Thong in the story of Phuang Malai Thong. These brave heroines successfully perform both the most difficult female and male tasks at the same time. The old misconception about women should be changed and a woman with masculine capability is promoted. She should no longer be considered as a weak human being. It seems that the poet of the story of Kaeo $\mathrm{Na} \mathrm{Ma}$ tries to suggest that Thai woman should have freedom in love and in her own destiny. He encourages Thai women to step out and to show their potential by taking more roles in society. The poet seems to be certain that Thai women can wear more than one mask, that is, they can hold more than one position and can do more than one duty at the same time. Some brave and clever women both in Thai society during the early Bangkok period and some unconventional female characters in some Thai literary works might have influences on Nang Kaeo's characteristics. It is possible that the poet intentionally expresses his admiration towards these actual persons and unconventional female characters by effectively creating Nang Kaeo. No matter how unconventional Nang Kaeo is, she is still in the conventional framework of a Thai heroine. Despite the poet's attempt to underline Nang Kaeo's knowledge and ability, he still insists that beauty is a typical characteristic of Thai heroines. The hero's need to remove the heroine's horse 
face before appointing her his queen proves the necessity of the heroine's beauty as well as the denial of an ugly heroine in Thai tales.

\section{References}

Akhavit Ruengrong. 1996. An Analytical Study of Kaeo Na Ma. M.A. Thesis, Chulalongkorn University. [in Thai]

Bot Lakhon Nok Rueang Kaeo Na Ma. 2001. Bangkok: The Fine Arts Department. [in Thai]

Chaiwichit (Phueak), Phraya. 1975. Yo Phra Kiat Sam Ratchakan. Bangkok: Bangkrabue. [in Thai]

Chatuporn Misakul. 1997. An Analytical Study of Lakhon Nok by Prince Phuwanetnarinrit. M.A. Thesis, Chulalongkorn University. [in Thai]

Cholada Ruengruglikit. 1996. Rup Nan Samkhan Chanai: Sueksa Chak Tualakhon Fai Chai Nai Wannakhadi Thai. Warasan Phasa Lae Wannakhadi Thai 13(1996):41-56. [in Thai]

Collins Cobuild English Language Dictionary. 1994. England: Clays.

Damrongrachanuphap, Somdet Phrachao Borommawongthoe Kromphraya. 1964. Tamnan Lakhon Inao. Thonburi: Po. Phitsanakha. [in Thai]
Damrongrachanuphap, Somdet Phrachao Borommawongthoe Kromphraya. 1973. Chiwit Lae Ngan Khong Sunthorn Phu. Bangkok: Sinlapabannakhan. [in Thai]

Kanchanakkhaphan. 1998. Samnuanthai. $4^{\text {th }}$ ed. Bangkok: Thailand-Japan Technology Promotion Association. [in Thai]

Khan Thong. Bangkok: Ratcharoen. [in Thai]

Kaeo Na Ma. 1957. Bangkok: Ratcharoen. [in Thai]

Leech, Geoffrey. 1975. Semantics. London: Penguin.

Nithan Khamklon Rueang Phra Aphai Mani. 1966. $9^{\text {th }}$ ed. Bangkok: Sinlapabannakhan. [in Thai]

Phuang Malai Thong. Bangkok: Ratcharoen. [in Thai]

Plaek Sinlapakamphiset. 1986. Photchananukrom Khamphong Thai-Malayu. Bangkok: The Royal Institute. [in Thai]

Rueang Inao Phra Ratchaniphon Ratchakan Thi Song. $11^{\text {th }}$ ed. 1971. Bangkok: Sinlapabannakhan. [in Thai]

Saranukrom Watthanatham Thai Phak Nuea. 1999. Bangkok: Saranukrom Watthanatham Thai Phak Nuea Foundation Siam Commercial Bank. [in Thai] 
The Meanings of the Horse-Faced Mask in Kaeo Na Ma

So Phlainoi. 1978. Nithan Wannakhadi.

$2^{\text {nd }}$ ed. Bangkok: Ruamsan.

[in Thai]

The Royal Institute Dictionary. 1999.

Bangkok: Nanmeebooks. [in Thai] 